Original Article

\title{
PROTECTIVE EFFECT OF ACORUS CALAMUS RHIZOME IN PARACETAMOL EXPOSURE INDUCED HEPATOTOXICITY IN RATS: BIOCHEMICAL AND HISTOPATHOLOGICAL STUDY
}

\author{
G. SRIVIDYA ${ }^{1}$, K. ADILAXMAMMA², C. H. SRILATHA ${ }^{3}$ \\ ${ }^{1.2}$ Department of Veterinary Pharmacology and Toxicology, ${ }^{3}$ Department of Veterinary Pathology, ${ }^{1} \mathrm{~N}$. T. R College of Veterinary Science, \\ Gannavaram, 2,3College of Veterinary Science Tirupati, Andhrapradesh \\ Email: vidyaprasad125@gmail.com \\ Received: 22 Jan 2018, Revised and Accepted: 15 Apr 2018
}

\section{ABSTRACT}

Objective: To study the hepatoprotective activity of an aqueous and alcoholic extract of Acorus calamus rhizomes against the paracetamol induced hepatotoxicity in rats.

Methods: Hepatotoxicity was induced by oral administration of paracetamol and chemical parameters such as Glutathione peroxidase, Glutathione reductase, Glutathione, Catalase, lipid peroxidation and histopathological changes in liver was studied by comparing with Silymarin, a standard hepatoprotective drug.

Results: Treatment of rats with aqueous and alcoholic extract of Acoruscalamus rhizome after paracetamol administration normalized the altered levels of above parameters which may comparable with Silymarin and Vit-E. The hepatoprotective activity was confirmed by histopathological examination of the liver tissue of control and treated animals.

Conclusion: Based on the result it can be concluded that Acorus calamus rhizome possesses hepatoprotective effect against paracetamol-induced hepatotoxicity in rats.

Keywords: Acorus calamus rhizome, Paracetamol, Silymarin, Vit-E, Hepatoprotection

(C) 2018 The Authors. Published by Innovare Academic Sciences Pvt Ltd. This is an open access article under the CC BY license (http://creativecommons.org/licenses/by/4.0/) DOI: http://dx.doi.org/10.22159/ijcpr.2018v10i3.27218

\section{INTRODUCTION}

Hepatotoxicity is one of the major adverse effects produced by many of the drugs. Hepatic disorders are the most common and serious health problems in animals and human beings. Drugs accounted for $50 \%$ of the liver failure out of which $39 \%$ is due to acetaminophen [1].

Acorus calamus is a semiaquatic perennial aromatic herb with creeping rhizomes belonging to the family Araceae. It is commonly called as vacha, vasa, sweet flag etc. It is commonly used to protect the children from kapha disorders and for the improvement of the intelligence and as a memory enhancer. The rhizome powder of A. calamus is used in the training of talking birds. The medicated oil of calamus roots is used externally for massages to relieve vata and kapha disorders [2].

The rhizomes of A. calamus possess spasmolytic [3], ectoparasiticide, insect repellant [4], anti-secretagogue, antiulcer and cytoprotective [5], antidiarrheal [3], hypolipidemic [6], anthelmintic and antibacterial [7], neuroprotective [8], larvicidal [9], antioxidant [10], bio pesticide [11], antiproliferative and immunosuppressive [12] anticonvulsant [13] and antifungal [14], properties.

However, a perusal of available literature revealed no reports on the antihepatotoxic potential of Acoruscalamus extract of the rhizome. Hence the present study is designed to screen the ethanolic and aqueous extract of the rhizome of Acoruscalamus for its hepatoprotective effect in male rats.

\section{MATERIALS AND METHODS}

Paracetamol IP was procured from M/S Granules India as gift sample, Silymarin was procured from Microlabs Bangalore as gratis. All other chemicals used in the study were of analytical grade and procured from a standard supplier.

\section{Collection and identification of plant material}

Whole plant of Acoruscalamus was collected from the local market and surrounding areas of Tirupati, Andhra Pradesh, India. The plant was identified and authenticated by the herbarium specialist, Department of Botany, S. V. University, Tirupati.

Preparation of Alcoholic extract of Acoruscalamus rhizome

Acoruscalamus rhizomes were dried in shade, later they were powdered and extracted $(1.5 \mathrm{~kg})$ successively with 30 liters of $60 \%$ alcohol in a soxhalet extractor for 18-20 h. The extract was distilled and concentrated to dryness under reduced pressure and controlled temperature $\left(40-50{ }^{\circ} \mathrm{c}\right.$ ) and finally freeze-dried. The ethanolic extract yielded a weight of $150 \mathrm{~g}(10 \% \mathrm{w} / \mathrm{w})$.

\section{Preparation of Aqueous extract of Acoruscalamus rhizome}

The dried rhizomes of Acoruscalamuswere powdered and the powdered material was taken in a round bottom flask and was extracted with water for $48 \mathrm{~h}$ at room temperature. After $48 \mathrm{~h}$, the solution was concentrated in a rotatory evaporator. Aqueous and alcoholic extract of Acoruscalamus was suspended in 0.5\% CMC.

\section{Table 1: Experimental design}

$\begin{array}{ll}\text { Group I } & 0.5 \% \text { Carboxymethylcellulose } p . o \text { for ten days } \\ \text { Group II } & \text { Paracetamol @ } 2 \mathrm{~g} / \mathrm{kg} p . o \text { on Day one+0.5\% Carboxymethylcellulose } p . o \text { for ten days } \\ \text { Group III } & \text { Paracetamol @ } 2 \mathrm{~g} / \mathrm{kg} p . o \text { on Day one+Ethanolic extract of Acoruscalamus rhizome }(600 \mathrm{mg} / \mathrm{kg}) p . o \text { for ten days } \\ \text { Group IV } & \text { Paracetamol @ } 2 \mathrm{~g} / \mathrm{kg} p . o \text { on Day one+Aqueous extract of } \text { Acoruscalamus rhizome }(600 \mathrm{mg} / \mathrm{kg}) p . o \text { for ten days } \\ \text { Group V } & \text { Paracetamol @ } 2 \mathrm{~g} / \mathrm{kg} p . o \text { on Day one+Silymarin @ } 25 \mathrm{mg} / \mathrm{kg} p . o \text { for ten days } \\ \text { Group VI } & \text { Paracetamol@ } 2 \mathrm{~g} / \mathrm{kg} p . o \text { on Day one+Vitamin E }(30 \mathrm{mg} / \mathrm{kg}) p . o \text { for ten days }\end{array}$




\section{Experimental animals}

Male albino rats of wistar strain weighing 150-200g were obtained from Department of Laboratory Animal Medicine, TANUVAS, Madhavaram milk colony, Chennai. The animals were maintained under standard laboratory conditions with food and water adlibitum. Approval of the experimental protocol was obtained prior to the conduct of the experiment from the institutional animal ethics and biosafety committee. The experiment was conducted in Department of Pharmacology and Toxicology, College of Veterinary Science, Tirupati.

Twenty four hours after the last day of treatment blood was collected from all the experimental animals by retrobulbar plexus puncture under ether anesthesia and whole livers were collected after sacrificing the animals by decapitation. Blood samples were used for the estimation of RBC enzyme profile viz Glutathione Peroxidase (GPx) Activity: [15], Glutathione Reductase activity: Spectrophotometric method-[16], Erythrocytic Catalase activity: [17], Lipid peroxidation activity from hepatic tissue homogenate Thiobarbituric acid reactive substances [18] The liver specimens obtained from control and treated groups were fixed in $10 \%$ formalin ad stained with $\mathrm{H}$ and $\mathrm{E}$ stain.

\section{Statistical analysis:}

The data were subjected to statistical analysis by applying one way ANOVA as per the standard methods of Snedecor and Cochran [19]. Differences between means were tested using Duncan's multiple comparison tests and significance was set at $\mathrm{P}<0.05$ and $\mathrm{P}<0.01$.

Table 2: Effects of alcoholic and aqueous extracts of $A$. calamus rhizome on erythrocyte antioxidant system (Glutathione peroxidase $(\mathrm{U} / \mathrm{ml})$, Glutathione reductase $(\mathrm{U} / \mathrm{ml})$, catalase $(\mathrm{moles} / \mathrm{sec})$

\begin{tabular}{|c|c|c|c|c|}
\hline S. No. & Title & Glutathione peroxidase $\left(\mathrm{U} \mathrm{ml}^{-1}\right)$ & Glutathione reductase $\left(\mathrm{U} \mathrm{ml}^{-1}\right)$ & Catalase (moles sec-1) \\
\hline 1. & Group I & $72.45 \pm 1.75^{\mathrm{a}}$ & $40.81 \pm 0.77^{a}$ & $2.98 \pm 0.02^{\mathrm{a}}$ \\
\hline 2. & Group II & $47.58 \pm 3.65^{c}$ & $27.35 \pm 1.12^{\mathrm{d}}$ & $1.50 \pm 0.11^{\mathrm{c}}$ \\
\hline 3. & Group III & $60.38 \pm 1.19^{b}$ & $34.13 \pm 1.12^{\mathrm{b}}$ & $2.58 \pm 0.07^{b}$ \\
\hline 4. & Group IV & $62.50 \pm 1.33^{\mathrm{b}}$ & $31.50 \pm 0.72^{\mathrm{c}}$ & $2.63 \pm 0.11^{b}$ \\
\hline 5. & Group V & $67.38 \pm 1.17 \mathrm{ab}$ & $39.65 \pm 0.75^{a}$ & $3.02 \pm 0.01^{\mathrm{a}}$ \\
\hline 6. & Group VI & $61.81 \pm 2.19^{b}$ & $36.95 \pm 1.25^{\mathrm{b}}$ & $2.49 \pm 0.17^{b}$ \\
\hline
\end{tabular}

Table 3: Effects of alcoholic and aqueous extracts of $A$. calamus rhizome on glutathione (mg/dl) levels in serum

\begin{tabular}{|c|c|c|}
\hline S. No. & Title & Glutathione (mg dl-1) \\
\hline 1. & Group I & $6.40 \pm 0.27^{a}$ \\
\hline 2. & Group II & $1.45 \pm 0.07^{d}$ \\
\hline 3. & Group III & $5.58 \pm 0.15^{b}$ \\
\hline 4. & Group IV & $3.98 \pm 0.14^{c}$ \\
\hline 5. & Group V & $5.78 \pm 0.09 b$ \\
\hline 6. & Group VI & $5.30 \pm 0.21^{\mathrm{b}}$ \\
\hline
\end{tabular}

One way ANOVA, the values are mean $\pm S E, n=6$, Different superscripts $a, b, c, d$ are statistically significant at $P<0.001$ and $P<0.005$

Table 4: Effects of alcoholic and aqueous extracts of $A$. calamus rhizome on lipid peroxidation in hepatic tissue (nM MDA/g tissue)

\begin{tabular}{lll}
\hline S. No. & Title & Lipid peroxidation (nmol $\mathbf{~}^{-1}$ ) \\
\hline 1. & Group I & $32.80 \pm 0.35^{\mathrm{d}}$ \\
2. & Group II & $42.95 \pm 0.86^{\mathrm{a}}$ \\
3. & Group III & $36.78 \pm 0.41^{\mathrm{b}}$ \\
4. & Group IV & $38.00 \pm 0.44^{\mathrm{b}}$ \\
5. & Group V & $34.78 \pm 0.59^{\mathrm{c}}$ \\
6. & Group VI & $36.18 \pm 0.75^{\mathrm{bc}}$ \\
\hline
\end{tabular}

One way ANOVA, the values are mean \pm SE, $n=6$, Different superscripts $a, b, c, d$ are statistically significant at $P<0.001$ and $P<0.005$

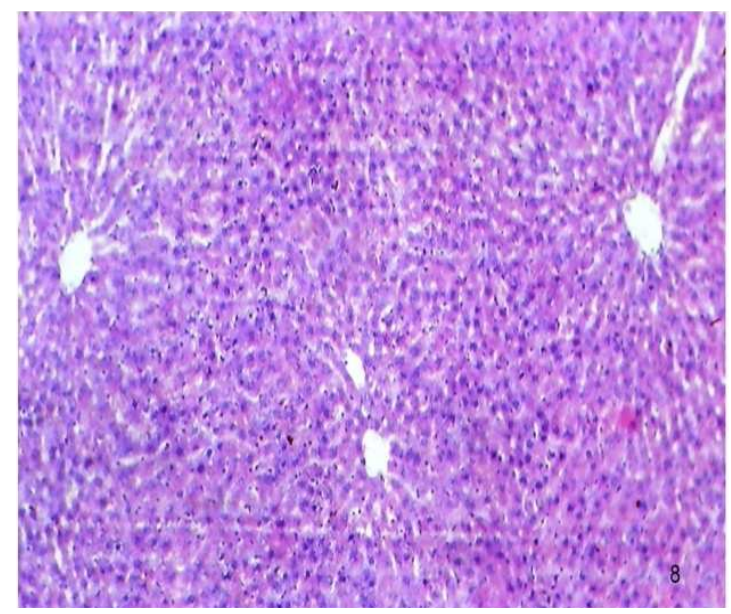

Group 1: Normal architecture of hepatic cells, $\mathrm{H}$ and $\mathrm{E} \times \mathbf{x}$

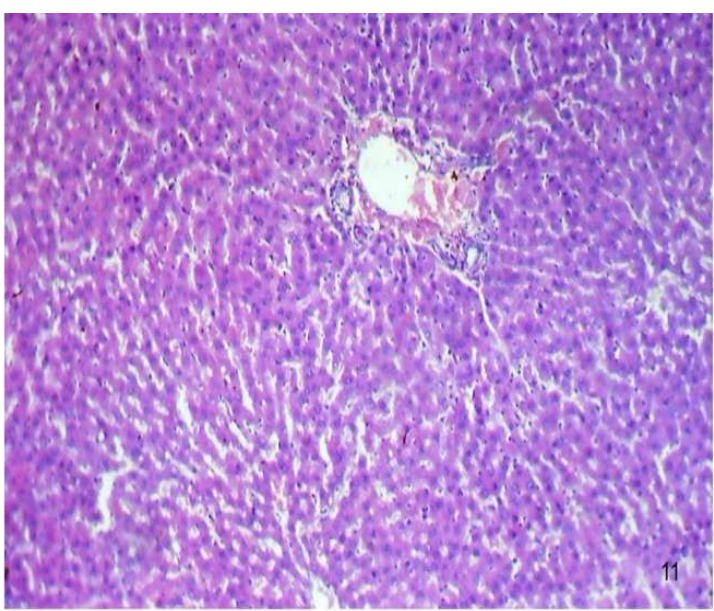

Group 2: Perivascular infiltration of mononuclear cells, $\mathrm{H}$ and $\mathrm{E}$ x 70 


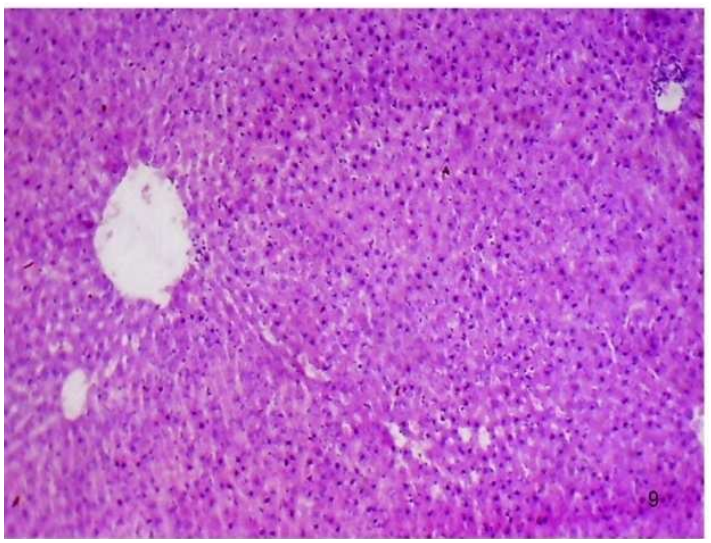

Group 5: Normal architecture of hepatic cells, $\mathrm{H}$ and $\mathrm{E} \times \mathrm{70}$

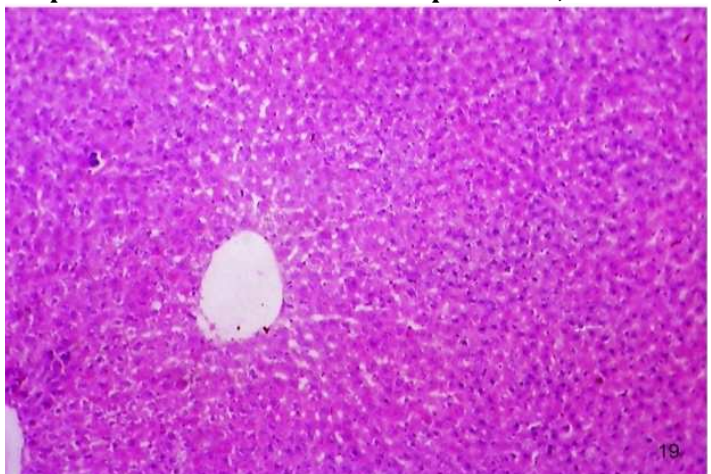

Group 6: Mild degenerative changes in liver parenchyma, $\mathrm{H}$ and $\mathrm{E}$ x 70

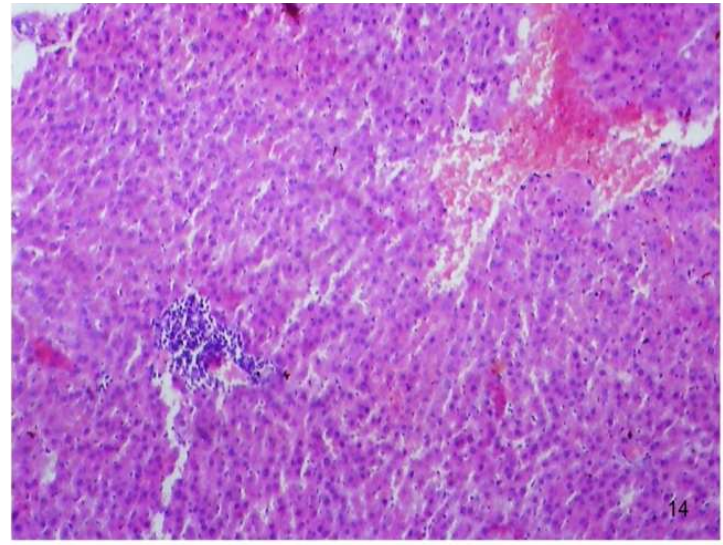

Group 2: Section showing sinusoidal haemorrhages, $\mathrm{H}$ and $\mathrm{E}$ x 70

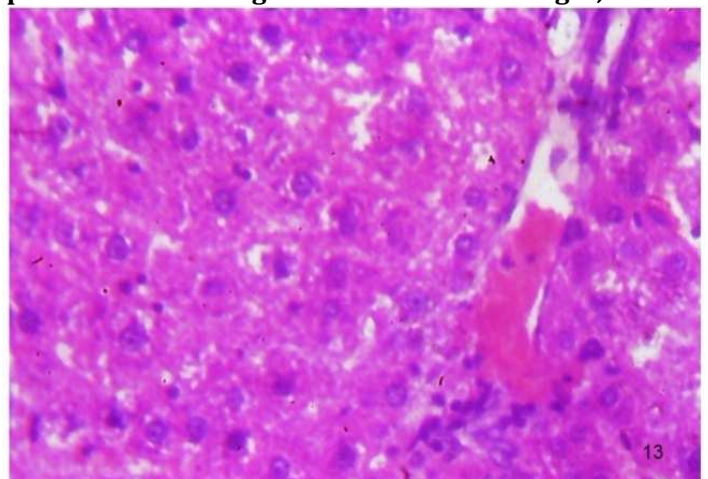

Group 3 and 4: Mild proliferation of bile duct, $\mathrm{H}$ and $\mathrm{E} \times \mathrm{70}$,

Fig. 1: Histoarchitecture of the liver in different treatment groups

\section{DISCUSSION}

In the present study, the levels of glutathione peroxidase were reduced in group 2 when compared to group 1 [20,21]. Silymarin prevented the reduction of glutathione peroxidase by protecting the glutathione depletion. Acoruscalamus prevented the altered glutathione peroxidase levels due to its antioxidant activity [22].

Glutathione reductase activity was reduced in group 2 which are in accordance with the other research findings on hepatotoxicity studies [23]. Vitamin E antagonized the glutathione reductase levels due to its antioxidant activity [24]. Acoruscalamus attenuated the altered glutathione reductase level due to its antioxidant activity [25].

Catalase, primarily antioxidant defence component is a tetrameric hemoprotein present in peroxisomes and catalyzes the dismutation of H2O2 reduces methyl and ethyl hydroperoxides. The liver, kidney and RBC possess relatively high levels of catalase [26].

The catalase activity in the paracetamol treated group was reduced significantly $(\mathrm{P}<0.01)$ when compared to control group which is in correlation with the reported data [27, 28]. Silymarin normalized the altered catalase levels [29]. Vitamin E increased catalase levels due to its antioxidant property [30]. Acoruscalamus prevented the reduction in catalase activity. In the present study glutathione levels were reduced significantly $(\mathrm{P}<0.01)$ in paracetamol toxic group when compared to the control group [20,27]. Silymarin antagonized the depletion of glutathione due to its free radical scavenging activity. Alcoholic extracts of Acoruscalamus showed marked protective effect than aqueous extract in glutathione depletion. Some of the studies reported that concurrent administration of Acoruscalamus extract with acrylamide significantly increased the glutathione levels in corpus striatum of rats [8]. The protective action of Vitamin E may be due to its antioxidant activity and also due to its increased red cells level of reduced glutathione [24].

Lipid peroxidation serves as a marker of oxidative stress. Lipid peroxidation is oxidative deterioration of polyunsaturated lipids and it involves ROS and transition metal ions. It is a molecular mechanism of cell injury leading to the generation of peroxides and lipid peroxides, which can be decomposed to yield a wide range of cytotoxin products, most of which are aldehydes such as MDA. A substantial increase in hepatic lipid peroxidation was evident by elevated MDA level in liver homogenate of the paracetamol administered group $[20,21]$. There is a direct correlation between glutathione depletion and lipid peroxidation. The elevated levels of MDA were suppressed by Silymarin. Silymarin reduced the MDA levels in tissue due to its antioxidant activity. Vit. E inhibits the lipid perodixation due to its antioxidant activity. Acoruscalamus reduced the paracetamol-induced lipid peroxidation.

The results of the present study revealed that treatment with aqueous and alcoholic extracts of Acoruscalamus normalized the activity of lipid peroxidation in liver tissue. The present study revealed the anti-lipid peroxidation activity of Acoruscalamus against paracetamol-induced lipid peroxidation in rats. Hence, the Acoruscalamus rhizomes can be used in the treatment of liver disorders after a detailed investigation of active compounds and the exact mechanism involved in the hepatoprotective activity.

In the present study, histopathological findings such as degeneration of hepatic cells sinusoidal haemorrhages and bile duct proliferation were noticed in group II $[20,31]$. Treatment with silymarin (group V), Vit. E (group VI) and Acoruscalamus (Group III and IV) preserved the structural integrity of the hepatic cellular architecture.

The present study demonstrates the antioxidative capacity of Acoruscalamus. The antioxidative effect inturn could have protected the decrease of GSH and other enzymes restoring the free radical scavenger's enzymatic activity. Thus, the use of Acoruscalamusmay be recommended for lifestyle-related diseases including hepatic diseases and also to improve the general health condition in animals including human beings. Extensive studies in target species should be preceeded before the clinical application of Acoruscalamus as an antioxidant agent. 


\section{AUTHORS CONTRIBUTIONS}

All the author have contributed equally

\section{CONFLICT OF INTERESTS}

\section{Declared none}

\section{REFERENCES}

1. www.fda.gov@google.com. [Last accessed on 20 Dec 2017]

2. Kulkarni PH. Ayurveda Herbs: Indian Medical Science Series No.106; 1998. p. 73.

3. Gilani AU, Shah AJ, Ahmad M, Shaheen F. Antispasmodic effect of Acoruscalamus Linn is mediated through calcium channel blockade. Phytother Res 2006;20:1080-4.

4. Ghosh S, Sharma AK, Kumar S, Tiwari SS, Rastogi S, Srivastava S. In vitro and in vivo efficacy of acoruscalamus extract against rhipicephalus (Boophilus) microplus. Parasitol Res 2011;108:361-70.

5. Rafatullah S, Tariq M, Mossa JS, Al-yahya MA, Al Said MS, Ageel AM. Antisecretagogue, antiulcer and cytoprotective properties of Acoruscalamus in rats. Fitoterapia 1994;65:1, 19-23.

6. Parab RS, Mengi SA. Hypolipidemic activity of Acoruscalamus L. in rats. Fitoterapia 2002;73:451-5.

7. Gaw MC, Jager AK, Van Staden J. Isolation of $\beta$-asarone an antibacterial and anthelmintic compound from Acoruscalamus in South Africa. South Afr J Bot 2002;68:31-5.

8. Pradeep K, Vinay K, Ali MM, Maurya RR, Handa SS, Srimal RC. Protective effect of Acoruscalamus against Acrylamide Induced Neurotoxicity. Phytother Res 2002;16:256-60.

9. Suryadevara P, Khanan P. Screening of plant extracts for larvicidal activity against Culexquinquefasciatus. J Nat Remedies 2002;2:186-8.

10. Ulyana MA, Daniel EA, Jun M, Michael HN, Edward J. Antioxidant capacities of ten edible North American plants. Phytother Res 2002;16:63-5.

11. Rani AS, Satyakala M, Murty USN. Acoruscalamus linn: an important medicinal plant and source of potent biopesticide. Proceedings of the National Academy of Science India Section B, Biological Sciences 2003;73:1-15.

12. Mehrotra S, Mishra KP, Maurya R, Srimal RC, Yadav VS, Pandey $\mathrm{R}$, et al. Anticellular and immunosuppressive properties of ethanolic extract of Acoruscalamus rhizome. Int Immunopharmacol 2003;3:53-61.

13. Yende SR, Harle UN, Bore VV, Bajaj AO, Shroff KK, Vedal YD. Reversal of neurotoxicity induced cognitive impairment associated with Phenytoin and Phenobarbital by Acoruscalamus in mice. J Herbal Med Toxicol 01/2009;3:111-5.

14. Jaripa-Begum, Sohrab H, Yusuf M, Chowdary JU, Husaain MM, Begum HA, et al. In vitro antifungal activity of azaron isolated from the rhizome extract of Acoruscalamus L. Pakistan J Biol Sci 2004;7:1376-9.

15. Paglia DE, Valentine WN. Studies on the quantitative and qualitative characterization of erythrocyte glutathione peroxidase. J Laboratory Clin Med 1967;77:158-9.

16. Raghuramulu. Manual of laboratory techniques NIN ICMR Jamia Osmania, Hyderabad; 1983. p. 204-6.

17. Britton C, Machlly AC. Assay of catalase and peroxidises. Methods Enzymol 1956;136:765-8.

18. Yagi R. Assay for lipid peroxides in animal tissues by the thiobarbituric acid reaction. Anal Biochem 1984;95:351-8.

19. Snedecor WG, Cochran GW. Statistical methods. $8^{\text {th }}$ ed. Iowa State University Press, Ames, USA; 1994.

20. Kumar G, Banu GS, Pandian. Evaluation of antioxidant activity of Trianthemaportulcastrum. Indian J Pharmacol 2005;37:331-3.

21. Ahmed MB, Khater MR. Evaluation of the protective potential of Ambrosia martima extract on acetaminophen-induced liver damage. J Ethnopharmacol 2001;75:169-74.

22. Manikandan S, Sheeladevi R. Antioxidant poperty of $\alpha$-asarone against noise stress induced changes in different regions of rat brain. Pharmacol Res 2005;52:467-74.

23. Kumar G, Sharmila Banu G, Vakannan V, Rajasekhara Pandian M. Antihepatotoxic effect of $\beta$-carotene on paracetamol induced hepatic damage in rats. Indian J Exp Biol 2004;43:351-5.

24. Suhail M, Ahmad I. In vivo effects of actaminophen on rat RBC and role of vitamin E. Indian J Exp Biol 1995;33:269-71.

25. Acuna UM, Atha DE, Ma J, Nee MH, Kennelly EJ. Antioxidant capacities of ten edible North American plants. Phytother Res 2002;161:63-5.

26. Yu BP. Cellular defences against damage from reactive oxygen species. Physiology reviews 1994;74:279-318.

27. Rajesh B, Parames CS. The protein fraction of Phyllanthusniruri plays a protective role against acetaminophen induced hepatic disorders via its antioxidant properties. Phytother Res 2006;20:595-601.

28. Kim ST, Kim JD, Ahn SH, Ahn GS, Lee YIK, Jeong YS. Hepatoprotective and antioxidant effects of Alnusjaponica extracts on acetaminophen induced hepatotoxicity in rats. Phytother Res 2004;18:971-5.

29. Linn, Hsu YF, Lin TC, Hsu My. Antioxidant and hepatoprotective effects of punicalagin and punicalin on acetaminophen induced liver damage in rats. Phytother Res 2001;15:206-21.

30. Shaiakhmetova HM, Kovalenko VM, Bondarenko LB, Kuzemenko IV. Antioxidant effectiveness of short-chain alpha tocopherol acetate in acute paracetamol poisoning in rats. Ukr Biokhinm Zh 2000;73:61-7.

31. Suresh Kumar SV, Sujatha C, Syamala J, Nagasudha B, Mishra SH. Protective effect of root extract of Operculinaturpethum Linn against paracetamol induced hepatotoxicity in rats. Indian J Pharm Sci 2006;68:32-5. 